\title{
Effects of photoperiod sensitivity genes Ppd-B1 and Ppd-D1 on spike fertility and related traits in bread wheat
}

\author{
Ignacio A. Ramirez ${ }^{1,2}$ | Pablo E. Abbate ${ }^{1}$ | Ignacio W. Redi $^{1}$ | Ana C. Pontaroli ${ }^{1,3}$ (ID
}

${ }^{1}$ Unidad Integrada Balcarce (Estación Experimental Agropecuaria Balcarce, Instituto Nacional de Tecnología Agropecuaria and Facultad de Ciencias Agrarias, Universidad Nacional de Mar del Plata), Balcarce, Buenos Aires, Argentina

${ }^{2}$ Monsanto's Beachell-Borlaug International Scholars Program, Soil \& Crop Sciences Department, Agrilife Research - Texas A\&M University System, College Station, Texas, USA

${ }^{3}$ Consejo Nacional de Investigaciones Científicas y Técnicas, Balcarce, Buenos Aires, Argentina

\section{Correspondence}

Ana Clara Pontaroli, Unidad Integrada Balcarce (Estación Experimental Agropecuaria Balcarce, Instituto Nacional de Tecnología Agropecuaria and Facultad de Ciencias Agrarias, Universidad Nacional de Mar del Plata), Balcarce, Buenos Aires, Argentina.

Email: pontaroli.ana@inta.gob.ar

Communicated by: K. Pillen

\begin{abstract}
Increasing grain yield is a key breeding goal in bread wheat. Several authors have suggested that a spike fertility index (SF), that is the quotient between grain number per unit spike (GNS) and spike chaff dry weight (SCDW), could be used as a yield-related selection criterion, especially if molecular markers were available. Here, the effects of Ppd-B1 and Ppd-D1 genes on SFm, GNSm and SCDWm (measured at maturity) and the relationship between these variables were analysed in field experiments carried out during three crop seasons at Balcarce, Argentina, on an association mapping population of 100 bread wheat cultivars of diverse origin released in Argentina between 1927 and 2010. Results show that both Ppd-B1 and Ppd-D1 are associated with SFm with similar effects. Cultivars with insensitive alleles at both genes showed a mean SFm 9.2\% greater than those with sensitive alleles at both genes; at each gene, difference in SFm between insensitive and sensitive alleles was $\sim 4.5 \%$. In turn, each gene showed a differential effect on GNSm and SCDWm, as Ppd-B1 was more related to SCDWm, whereas Ppd-D1 was only related to GNSm. Although more research needs to be carried out in order to ascertain the physiological pathway by which these genes affect spike fertility, this study represents a first approximation in order to elucidate the molecular and genetic basis underlying SF and related physiological traits.
\end{abstract}

\section{KEYWORDS}

breeding, fruiting efficiency, grain yield, selection

\section{INTRODUCTION}

Bread wheat (Triticum aestivum L.) is the most widely grown crop at a global scale and a major source of carbohydrates and proteins in human nutrition (Mahjourimajd et al., 2016), and current and future prospects indicate that its demand will continue to grow. This implies that breeding efforts need to focus on increasing yield, because the opportunities for adding new arable land to the cultivated area are limited. Thus, grain yield improvement has been, and it continues to be, one of the central goals in wheat breeding programmes worldwide (Dixon et al., 2009; Foulkes \& Reynolds, 2014; Mirabella et al., 2016; Rajaram, 2005). During the last 30-40 years, genetic and agronomic progress in wheat grain yield has been largely attributed to an increase in grain number (GN)/m² (Fischer, 2007; Foulkes et al., 2011; Reynolds et al., 2009; Shearman et al., 2005; Slafer et al., 1990). However, despite $\mathrm{GN} / \mathrm{m}^{2}$ is the trait that usually best explains yield and several authors have shown that it can be further increased (Abbate et al., 1998; Acreche et al., 2009; Foulkes et al., 2011; Parry et al., 2011; Reynolds et al., 2009), it is difficult to accurately determine it at early stages of a breeding programme, in which not enough seed is available to measure variables as per unit area. Therefore, it is necessary to use alternative, related traits as selection criteria.

According to Fischer's assimilate-based approach (Fischer, 1983), under optimal growing conditions (i.e., without water or nutrient limitations and in the absence of pests and diseases), GN in wheat can be considered as the product of (i) the duration of the spike growth period (SGP), (ii) the crop growth rate during the SGP, (iii) the dry weight partitioning to spikes during the SGP and (iv) the number of grains per unit of spike chaff dry weight (SCDW), that is a spike fertility (SF) index, also termed "fruiting efficiency" (Slafer et al., 2015). 
Abbate et al. (1998), working on Argentinean high-yielding cultivars, observed that $\mathrm{GN} / \mathrm{m}^{2}$ was mainly related to SF. Since then, many authors have shown the existence of conspicuous variation for this trait among cultivars of diverse origin (Abbate et al., 2013; Acreche, BriceñoFélix, Martín Sánchez, \& Slafer, 2008; Fischer, 2007; González et al., 2011; González-Navarro et al., 2015; Lázaro \& Abbate, 2012; Martino et al., 2015; Mirabella et al., 2016; Shearman et al., 2005). Interestingly, recent work has evidenced that SF is a moderately heritable trait, with low genotype $\times$ environment interaction (González-Navarro et al., 2015; Martino et al., 2015; Mirabella et al., 2016); moreover, a simple and fast methodology (Abbate et al., 2013) has been developed for high-throughput assessment of SF at maturity (SFm) in early breeding material using the dry weight of the chaff at maturity (spike weight after removing the grains) to provide an estimate of the spike dry weight at anthesis. Thus, it has been suggested that spike fertility can be used as a selection criterion in breeding programmes to develop high-yielding cultivars (Fischer, 2007, 2011; Foulkes et al., 2011; González et al., 2011; Lázaro \& Abbate, 2012; Abbate et al., 2013; González et al., 2014; Slafer et al., 2015; among others).

Despite SF appears to be under a relatively simple genetic control as compared to yield (Martino et al., 2015; Mirabella et al., 2016), virtually no candidate genes have been proposed specifically for this trait to date (Slafer et al., 2015). In this regard, several studies (Fischer, 2016; González et al., 2003, 2005; Whitechurch \& Slafer, 2002) have shown that modifications in day length during the spike growth phase, or changes in photoperiod sensitivity, affected fertile floret number at anthesis. In wheat, photoperiod response is mainly regulated by Ppd-A1, Ppd-B1 and Ppd-D1 genes (Law et al., 1978; Scarth \& Law, 1983; Welsh et al., 1973); "sensitive" alleles confer increase in thermal time to anthesis when the photoperiod is reduced, whereas "insensitive" ones make the plant insensitive to day length. Slafer et al. (1996), Slafer et al. (2001) and González et al. (2005), among others, have suggested increasing photoperiod sensitivity as a way to increase GNSm through a longer duration of the spike growth period before anthesis. It would be interesting to establish the degree to which photoperiod sensitivity genes affect GNSm, SCDWm and SFm. Thus, the aim of this study was to analyse the effects of Ppd-B1 and Ppd-D1 genes on SFm, GNSm and SCDWm in an association mapping population composed of 100 bread wheat cultivars of diverse origin, released between 1927 and 2010 in Argentina.

\section{MATERIALS AND METHODS}

\section{1 | Plant material}

An association mapping population composed of 100 bread wheat cultivars of diverse origin (namely Mexico, France, USA and Argentina; described in Vanzetti et al., 2013) released in Argentina between 1927 and 2010. The allelic constitution was determined by Vanzetti et al. (2013) using a molecular marker closely linked to Ppd-B1 (Díaz et al.,
2012) and a functional marker for Ppd-D1 (Beales et al., 2007) (Supporting information).

\section{2 | Crop management}

Three field experiments (termed Expt 1, Expt 2 and Expt 3) were carried out, respectively, during the 2013/14, 2014/15 and 2015/16 crop seasons at the experimental field of the Estación Experimental Agropecuaria Balcarce of the Instituto Nacional de Tecnología Agropecuaria (Balcarce, Argentina; $37^{\circ} 45^{\prime} \mathrm{S}, 58^{\circ} 18^{\prime} \mathrm{W}, 130 \mathrm{~m}$ a.s.l.). The experiments were conducted under no nutrient or water limitations, and pests and fungal diseases were chemically controlled.

Expt 1 was conducted under a split-plot design with two replicates. The treatments consisted of the combination of four sowing dates as a main plot, carried out approximately every 15 days starting in early June 2013 to generate different photoperiod conditions and 100 cultivars as the subplot. Each experimental unit consisted of a plot with 25 seeds sown in a single, 0.5-m-long row, $0.2 \mathrm{~m}$ interrow apart. Phenological dates (heading, anthesis and maturity) of each plot were recorded, and, at maturity, 15 spikes were collected randomly. Spikes were dried, weighted and threshed for measuring GNSm and SCDWm, and SFm was calculated as the quotient between GNSm and SCDWm, according to previously published methodology (Abbate et al., 2013).

Heading date information collected for each cultivar at each sowing date in Expt 1 was used for grouping cultivars into three groups of similar heading date (see Supporting information). In Expt 2 and Expt 3 , each cultivar was sown at one of each three sowing dates, in order for all cultivars to have similar heading date (around the first week of November). Expt 2 and Expt 3 were conducted under a randomized complete block design with two replicates. The experimental unit consisted of a 5.5 - $\mathrm{m}$-long seven-row plot, with a $0.2 \mathrm{~m}$ inter-row distance. GNSm, CDWm and SFm were determined as in Expt 1.

\section{3 | Statistical analysis}

Phenotypic information obtained from Expt 1, Expt 2 and Expt 3 was analysed along with the genetic information (i.e., the allelic constitution for Ppd-B1 and Ppd-D1 genes) obtained from previously published work (Vanzetti et al., 2013) using mixed models. The variance of data from Expt 1 was first analysed separately to assess sowing date effects, according to the following statistical model (model 1):

$$
y_{i j k l m}=\mu+\alpha_{i}+\rho_{j}+\gamma_{1}+\delta_{m}+\rho \gamma_{j l}+\rho \delta_{j m}+\gamma \delta_{l m}+\rho \gamma \delta_{j l m}+e_{i j k l m},
$$

where $\mu$ is the general mean of the trait (SFm, SCDWm or GNSm), $\alpha_{i}$ is the effect of the blocks, $\rho_{j}$ is the effect of the sowing date, $\gamma_{l}$ is the effect of the Ppd-B1 gene, $\delta_{m}$ is the effect of the Ppd-D1 gene, $\rho \gamma_{j l}$ is the interaction effect between sowing date and $P p d-B 1, \rho \delta_{j m}$ is the interaction effect between the sowing date and Ppd-D1, $\gamma \delta_{l m}$ is the interaction effect between Ppd-B1 and $P p d-D 1, \rho \gamma \delta_{j l m}$ is the interaction effect between sowing date, Ppd-B1 and Ppd-D1, and $e_{i j k l m}$ is the error (variance not explained by the model). 
The SFm, SCDWm and GNSm values of each cultivar at its optimal sowing date in Expt 1 were combined with data from Expt 2 and Expt 3 and analysed together. The statistical model used in the analysis of variance of combined data from Expt 1, Expt 2 and Expt 3 was as follows (model 2):

$y_{q k l m}=\mu+\alpha_{q}+\rho_{k(q)}+\gamma_{l}+\delta_{m}+\alpha \gamma_{q l}+\alpha \delta_{q m}+\gamma \delta_{l m}+\alpha \gamma \delta_{q l m}+e_{q i k l m}$,

where $\alpha_{q}$ is the effect of year, $\rho_{k(q)}$ is the block effect within each year (random effect), $\alpha \gamma_{q l}$ is the interaction effect between year and $P p d-B 1, \alpha \delta_{q m}$ is the interaction effect between year and Ppd-D1, $\alpha \gamma \delta_{q l m}$ is the interaction effect between year, Ppd-B1 and Ppd-D1, $e_{\text {qiklm }}$ is the error (variance not explained by the model). The remaining terms were already defined in the previous equation.

Data were checked for ANOVA assumptions (normal distribution, homoscedasticity and independence of errors) before analysis. A 0.05 significance level was used for all tests. Before ANOVA, a regression analysis between SFm and year of cultivar release was performed to rule out confounding effects (e.g., a selection bias). As a result, no significant effect was found $\left(R^{2}=.0342\right)$. The relative frequency of the different allelic combinations in "older" vs. "recent" cultivars (i.e., released before and after 2000 , respectively) was also determined and found to be fairly similar (Table S2). In addition, no effect of the population structure, as determined by genome-wide molecular marker analysis (Vanzetti et al., 2013), was found on the variables analysed in this study. Therefore, it was not included as a factor in the model.

The proportion of variance explained by the genes was estimated with the residual variances of models that included the cultivar and gene effects vs. those which did not include such effects.

Repeatability (Piepho \& Möhring, 2007) for each trait was estimated as broad-sense heritability using the standard least squares method, as proposed by Holland et al. (2003).

\section{3 | RESULTS}

The mean, maximum, minimum and genetic coefficient of variation for SFm, SCDWm and GNSm are shown in Table 1 for each experiment. Extensive genetic variation was observed at all traits and experiments, as indicated by genetic coefficient of variation values between 15.8 and $22.9 \%$.

No significant effect of the sowing date was found when SFm, SCDWm or GNSm was analysed in Expt 1 (Table 2). Nevertheless, to avoid confounding effects of different heading dates, only SFm,
SCDWm and GNSm values of each cultivar at its optimal heading date in Expt 1 (i.e., around the first week of November) were included in further combined analyses together with data from Expt 2 and Expt 3.

The combined statistical analysis of Expt 1, Expt 2 and Expt 3 showed that the insensitive allele at both Ppd-B1 and Ppd-D1 genes was associated with greater SFm values, with no gene $\times$ gene interaction (Tables 3 and 4).

No statistically significant difference was detected between genes on SFm (Table 4). Cultivars with insensitive alleles at both genes showed the highest SFm mean $(9.2 \%$ greater than SFm mean of cultivars with sensitive alleles at both genes). The difference between the insensitive and sensitive allele was 4.7 and $4.3 \%$ for $P p d-B 1$ and Ppd-D1, respectively (Table 4).

When analysing SCDWm, a significant effect of the Ppd-B1 gene was observed, as the insensitive allele decreased SCDWm by $9.2 \%$ as compared with the sensitive allele (Table 4) thereby increasing SFm. In the case of Ppd-D1, the allelic constitution did not affect SCDWm ( $p>.05)$.

A significant Ppd-B1 $\times$ Ppd-D1 interaction was observed on GNSm in Expt 1 (Table 2), but this was not confirmed in the combined analysis with data from all three experiments. Ppd-D1 gene showed a significant effect on GNSm, as the insensitive allele at this gene increased it by $4 \%$ as compared with the sensitive allele (Table 4). Conversely, allelic effects on GNSm at the Ppd-B1 gene were non-significant in Expt 1 (Table 2) and barely significant $(p=.04$ ) in the combined analysis, as compared with those at the Ppd-D1 gene $(p<.01$; Tables 2 and 3). In this case, the insensitive allele at this gene decreased GNSm by $3.4 \%$ as compared with the sensitive one (Table 4 ).

The proportion of variance explained by the genes was $3.5 \%$ for SFm (both genes), $4.2 \%$ for SCDWm (Ppd-B1 gene) and $4.7 \%$ for GNSm (both genes). The broad-sense heritability for SFm, SCDWm and GNSm was $0.56,0.47$ and 0.39 , respectively, indicating that the genotype effect was mildly repeatable even though there was a highly significant year effect in all variables (Table 3 ).

\section{DISCUSSION}

The use of SF as a selection criterion in wheat breeding programmes aimed at increasing grain yield has been profusely discussed in the literature (Abbate et al., 1998, 2013; Fischer, 2007, 2011; Foulkes et al., 2011; González et al., 2011; Lázaro \& Abbate, 2012). Martino et al. (2015) and Mirabella et al. (2016) found that this trait is moderately heritable with low genetic $\times$ environmental interaction and that it is

TABLE 1 Mean, maximum, minimum, percentual genetic coefficient of variation (CVg) and standard error (SE) values for spike fertility (SFm), spike chaff dry weight (SCDWm) and grain number/spike (GNSm) at maturity, at Experiment 1 (2013/14 crop season), Experiment 2 (2014/15 crop season) and Experiment 3 (2015/16 crop season), in Balcarce, Argentina

\begin{tabular}{|c|c|c|c|c|c|c|c|c|c|c|c|c|c|c|c|}
\hline Variable & \multicolumn{5}{|l|}{ Expt 1} & \multicolumn{5}{|l|}{ Expt 2} & \multicolumn{5}{|l|}{ Expt 3} \\
\hline SFm (grains/g) & 75.2 & 45.3 & 114.3 & 15.8 & 11.4 & 74.7 & 39.9 & 111.5 & 16.2 & 12.3 & 75.7 & 30.4 & 115.1 & 21.4 & 15.7 \\
\hline GNSm (grains/spike) & 49.8 & 29.5 & 71.4 & 15.8 & 7.9 & 44.9 & 21.5 & 66.3 & 17.9 & 8.0 & 44.5 & 24.1 & 65.9 & 19.5 & 8.7 \\
\hline
\end{tabular}


TABLE 2 Significance levels in the ANOVA of spike fertility (SFm), spike chaff dry weight (SCDWm) and grain number/spike (GNSm), at maturity, for Experiment 1 at Balcarce, Argentina

\begin{tabular}{lccc} 
Factor & $\begin{array}{l}\text { SFm } \\
\text { (grains/g) }\end{array}$ & $\begin{array}{l}\text { SCDWm } \\
\text { (g/spike) }\end{array}$ & $\begin{array}{l}\text { GNSm } \\
\text { (grains/spike) }\end{array}$ \\
\hline Block & 0.49 & 0.30 & 0.58 \\
\hline Sowing date (SD) & 0.12 & 0.26 & 0.56 \\
\hline Ppd-B1 (B1) & $<0.01$ & $<0.01$ & 0.44 \\
\hline Ppd-D1 (D1) & $<0.01$ & 0.20 & $<0.01$ \\
\hline SD $\times$ B1 & 0.99 & 0.43 & 0.23 \\
\hline$S D \times D 1$ & 0.74 & 0.83 & 0.85 \\
\hline$B 1 \times D 1$ & 0.66 & 0.10 & 0.01 \\
\hline$S D \times B 1 \times D 1$ & 0.98 & 0.99 & 0.88 \\
\hline
\end{tabular}

TABLE 3 Significance levels in the ANOVA of spike fertility (SFm), spike chaff dry weight (SCDWm) and grain number/spike (GNSm) at maturity for combined data from Experiments 1, 2 and 3 at Balcarce, Argentina

\begin{tabular}{llll} 
Factor & $\begin{array}{l}\mathrm{SFm} \\
\text { (grains/g) }\end{array}$ & $\begin{array}{l}\text { SCDWm } \\
\text { (g/spike) }\end{array}$ & $\begin{array}{l}\text { GNSm } \\
\text { (grains/spike) }\end{array}$ \\
\hline Year $(\mathrm{Y}$ ) & $<0.01$ & $<0.01$ & $<0.01$ \\
\hline Ppd-B1 (B1) & $<0.01$ & $<0.01$ & 0.04 \\
\hline Ppd-D1 (D1) & $<0.01$ & 0.78 & $<0.01$ \\
\hline $\mathrm{Y} \times$ B1 & 0.55 & 0.47 & 0.38 \\
\hline $\mathrm{Y} \times D 1$ & 0.82 & 0.43 & 0.54 \\
\hline B1 $\times D 1$ & 0.33 & 0.46 & 0.77 \\
\hline $\mathrm{Y} \times B 1 \times D 1$ & 0.39 & 0.67 & 0.06 \\
\hline
\end{tabular}

controlled by several genes. Nevertheless, to this date, no candidate genes have been postulated as underlying the control of SF (Slafer et al., 2015). Several authors did suggest the use of Ppd-B1 (Worland et al., 1998) and Ppd-D1 (Börner et al., 1993; Worland, 1996; Worland et al., 1988; Worland et al., 1998) genes to directly increase grain number per unit area and yield in European wheat cultivars.

The present study shows that the insensitive alleles of the Ppd-B1 and Ppd-D1 genes are associated with an increase in SFm, independently of Ppd genes' well-known and widely reported effect on determining heading date in wheat and other cereals. Several authors (González et al., 2005; Worland, 1996; Worland et al., 1998) have suggested that $P p d-D 1$ shows stronger effects than $P p d-B 1$ in traits such as spikelet number, grains per spikelet and heading date. Contrarily, our results show no differences between genes when SFm is analysed. The absence of interaction between Ppd-B1 and Ppd-D1 on SFm indicates that the effects of these genes are additive and that the insensitive alleles can be combined to achieve higher SFm values. In addition, the absence of interaction between the genes and the environment and their repeatability add evidence in support for their manipulation as a means of increasing SFm in the context of a breeding programme. Moreover, these results could partially explain the differences in SF found by Fischer (2016) between two closely related cultivars, 'Yecora' and 'Cajeme', which differ in their Ppd-D1 constitution.

Surprisingly, when GNSm was analysed, a differential effect of $P p d-D 1$ was observed as compared with that of Ppd-B1 (Figure S1). $P p d-D 1$ showed a highly significant effect on GNSm, as this variable increased by an average of $4 \%$ (along with a $4.3 \%$ increase in SFm) on the presence of the insensitive allele as compared with the sensitive one, but it did not affect SCDWm. On the other hand, the presence of the insensitive vs. the sensitive allele at the Ppd-B1 gene increased SFm by $4.7 \%$, similarly to what was observed at Ppd-D1, but in this case, SCDWm was reduced by $9.2 \%$, along with a $3.4 \%$ decrease in GNSm (Figure S1). Similar results were obtained with Ppd-D1 (then termed Ppd1) by Börner et al. (1993) and Worland et al. (1998) who, working with a few single chromosome recombinant lines derived from the cross between the tall UK cultivar 'Cappelle Desprez' and the semidwarf Italian cultivar 'Mara', observed an increase close to $7 \%$ in GNSm when the insensitive allele was present. Also in regards to Ppd-D1, our results differ from those of González et al. (2005) and those discussed by Slafer et al. (2015), who suggested the use of cultivars with the sensitive allele in order to increase the number of fertile florets and, consequently, GNSm. In the case of Ppd-B1, and under certain environmental conditions, Worland et al. (1998) found similar but weaker effects of this gene on GNSm as compared with those observed for Ppd-D1. Our results, carried out using a much wider array of genetic backgrounds, suggest an opposite effect of Ppd-B1 on GNSm. Nevertheless, as shown

TABLE 4 Differential effect of insensitive (i) and sensitive (s) alleles at the Ppd-B1 and Ppd-D1 genes on spike fertility (SFm), spike chaff dry weight $(\mathrm{SCDWm})$ and grain number per spike (GNSm) measured at maturity, for combined data from Experiments 1, 2 and 3 at Balcarce, Argentina

\begin{tabular}{|c|c|c|c|c|c|c|c|c|c|c|c|c|}
\hline \multirow[b]{2}{*}{ Alleles } & \multicolumn{4}{|l|}{ SFm } & \multicolumn{4}{|l|}{ SCDWm } & \multicolumn{4}{|l|}{ GNSm } \\
\hline & $\begin{array}{l}\text { Mean } \\
\text { (grains/g) }\end{array}$ & $\begin{array}{l}\text { Difference } \\
\text { (grains/g) }\end{array}$ & (\%) & & Mean (g) & Difference (g) & (\%) & & $\begin{array}{l}\text { Mean } \\
\text { (grains/spike) }\end{array}$ & $\begin{array}{l}\text { Difference } \\
\text { (grains/spike) }\end{array}$ & (\%) & \\
\hline i & 77.6 & 3.5 & 4.7 & A & 0.59 & -0.06 & -9.2 & B & 45.1 & -1.6 & -3.4 & B \\
\hline$s$ & 74.2 & & & B & 0.65 & & & $A$ & 46.7 & & & A \\
\hline$s$ & 74.3 & & & B & 0.61 & & & $A$ & 45.0 & & & B \\
\hline
\end{tabular}

Different letters (A, B) indicate statistically significant difference between treatment means $(p<.05)$. 
in Figure S1, higher SFm values would be expected when combining insensitive alleles at both genes.

Only $9 \%$ of the cultivars evaluated in the present study had insensitive alleles at both Ppd genes. However, this group included both Argentinean cultivars that have had wide diffusion, for example 'Marcos Juarez INTA' (first Argentinean cultivar with dwarfing alleles, marketed for more than 25 years), as well as recently released cultivars without evident unfavourable characteristics, $71 \%$ of which are of short and intermediate cycle. Therefore, there is no reason to suppose that the combination of insensitive alleles at both loci cannot be used in the generation of cultivars with higher grain number per unit area, although the results obtained at the spike level need to be validated at the crop level (i.e., through the assessment of GN/ $\mathrm{m}^{2}$ ). Also, eventual trade-offs of this selection strategy should be investigated, such as a possible negative association between SF (or grain number per unit area) and grain weight (Martino et al., 2015) or other yield-related traits.

Spike chaff dry weight only showed association with Ppd-B1, as lower average SCDWm values were related to the presence of the insensitive allele. This is the first report, which we are aware of, that describes a gene related to this trait.

The relatively low percentage of phenotypic variance explained by the genes (3.5-4.7\% depending on the trait and gene) suggests that, although the effects of both Ppd-B1 and Ppd-D1 on the assessed variables were repeatable even under different environmental conditions (as reflected by a highly significant year effect on all variables), many additional genes are possibly involved in the control of SF, GNS and SCDW. Further work on the identification of such genes would help design breeding strategies for increasing SF through the concurrent selection of the best allelic combinations at several loci.

\section{5 | CONCLUSION}

The results from this work show that the presence of photoperiodinsensitive alleles at both Ppd-B1 and Ppd-D1 genes is associated with higher SF, showing similar and additive effects. The allele effects, however, differed in their origin: insensitivity at Ppd-B1 reduced SCDW more than GNS, while insensitivity at Ppd-D1 increased GNS and left SCDW unchanged.

Although more research needs to be carried out in order to ascertain the physiological pathway by which these genes affect SF, our study represents a first approximation in order to elucidate the molecular and genetic basis underlying SF and physiological traits related to SF.

\section{ACKNOWLEDGEMENTS}

We would like to thank Grupo Trigo Balcarce for their help and commitment with the experiments. A scholarship granted to I. A Ramirez by the Monsanto's Beachell-Borlaug Scholarship Program (Texas A\&M Univ. System/AgriLife Research) is acknowledged. This work is part of a thesis by I. A. Ramirez in partial fulfilment of the requirements for the Doctor's degree (Facultad de Ciencias Agrarias, Universidad Nacional de Mar del Plata, Argentina).

\section{ORCID}

Ana C. Pontaroli (iD http://orcid.org/0000-0002-2605-7668

\section{REFERENCES}

Abbate, P. E., Andrade, F. H., Lázaro, L., Bariffi, J. H., Berardocco, H. G., Inza, V. H., Marturano, F. (1998). Grain yield increase in recent Argentine wheat cultivars. Crop Science, 38, 1203-1209. https://doi. org/10.2135/cropsci1998.0011183X003800050015x

Abbate, P. E., Pontaroli, A. C., Lázaro, L., \& Gutheim, F. (2013). A method of screening for spike fertility in wheat. Journal of Agricultural Science, 151(3), 322-330. https://doi.org/10.1017/S002185961200 0068

Acreche, M. M., Briceño-Félix, G., Martín Sánchez, J. A., \& Slafer, G. A (2008). Physiological bases of genetic gains in Mediterranean bread wheat yield in Spain. European Journal of Agronomy, 28(3), 162-170. https://doi.org/10.1016/j.eja.2007.07.001

Acreche, M. M., Briceño-Félix, G., Sánchez, J. A. M., \& Slafer, G. A. (2009). Grain number determination in an old and a modern Mediterranean wheat as affected by pre-anthesis shading. Crop and Pasture Science, 60(10), 271-279. https://doi.org/10.1071/CP08236

Beales, J., Turner, A., Griffiths, S., Snape, J. W., \& Laurie, D. A. (2007). A pseudo-response regulator is misexpressed in the photoperiod insensitive Ppd-D1a mutant of wheat (Triticum aestivum L.). TAG. Theoretical and Applied Genetics., 115, 721-733. https://doi.org/10.1007/ s00122-007-0603-4

Börner, A., Worland, A. J., Plaschke, J., Schumann, E., \& Law, C. N (1993). Pleiotropic effects of genes for reduced height (Rht) and daylength insensitivity $(P p d)$ on yield and its components for wheat grown in Middle Europe. Plant Breeding, 111, 204-216. https://doi. org/10.1111/j.1439-0523.1993.tb00631.x

Díaz, A., Zikhali, M., Turner, A. S., Isaac, P., \& Laurie, D. A. (2012). Copy number variation affecting the Photoperiod-B1 and Vernalization-A1 genes is associated with altered flowering time in wheat (Triticum aestivum). PLoS ONE, 7, 1-11.

Dixon, J., Braun, H., Kosina, P., \& Crouch, J. (2009). Wheat facts and future. Mexico DF, Mexico: CIMMYT. 95 p.

Fischer, R. A. (1983). Wheat. In W. H. Smith, \& S. J. Bante (Eds.), Potential productivity of field crops under different environments (pp. 129-154). International Rice Research Institute, Los Baños: Philippines.

Fischer, R. A. (2007). Understanding the physiological basis of yield potential in wheat. Journal of Agricultural Science, 145(2), 99-113. https://doi.org/10.1017/S0021859607006843

Fischer, R. A. (2011). Wheat physiology: A review of recent developments. Crop and Pasture Science, 62(2), 95-114. https://doi.org/10. 1071/CP10344

Fischer, R. A. (2016). The effect of duration of the vegetative phase in irrigated semi-dwarf spring wheat on phenology, growth and potential yield across sowing dates at low latitude. Field Crops Research, 198, 188-199. https://doi.org/10.1016/j.fcr.2016.06.019

Foulkes, M. J., \& Reynolds, M. P. (2014). Breeding challenge: improving yield potential. In: V. O. Sadras \& D.F. Calderini (Eds.), Crop physiology: Applications for genetic improvement and agronomy (pp. 397-421), 2nd ed. Amsterdam, The Netherlands: Elsevier Inc.

Foulkes, M. J., Slafer, G. A., Davies, W. J., Berry, P. M., SylvesterBradley, R., Martre, P., Calderini, D. F., Griffiths, S., Reynolds, M. P. (2011). Raising yield potential of wheat. III. Optimizing 
partitioning to grain while maintaining lodging resistance. Journal of Experimental Botany, 62(2), 469-486. https://doi.org/10.1093/jxb/ erq300

González, F. G., Aldabe, M. L., Terrile, I. I., \& Rondanini, D. P. (2014). Grain weight response to different postflowering source:Sink ratios in modern high-yielding Argentinean wheats differing in spike fruiting efficiency. Crop Science, 54(1), 297-309. https://doi.org/10.2135/ cropsci2013.03.0157

González, F. G., Slafer, G. A., \& Miralles, D. J. (2003). Grain and floret number in response to photoperiod during stem elongation in fully and slightly vernalized wheats. Field Crops Research, 81, 17-27. https://doi.org/10.1016/S0378-4290(02)00195-8

González, F. G., Slafer, G. A., \& Miralles, D. J. (2005). Pre-anthesis development and number of fertile florets in wheat as affected by photoperiod sensitivity genes Ppd-D1 and Ppd-B1. Euphytica, 146, 253-269.

González, F. G., Terrile, I. I., \& Falcón, M. O. (2011). Spike fertility and duration of stem elongation as promising traits to improve potential grain number (and yield): Variation in modern Argentinean wheats. Crop Science, 51(4), 1693-1702. https://doi.org/10.2135/cropsc i2010.08.0447

González-Navarro, O. E., Griffiths, S., Molero, G., Reynolds, M. P., \& Slafer, G. A. (2015). Dynamics of floret development determining differences in spike fertility in an elite population of wheat. Field Crops Research, 172, 21-31. https://doi.org/10.1016/j.fcr.2014.12.001

Holland, J. B., Nyquist, W. E., \& Cervántes-Martínez, C. T. (2003). Estimating and interpreting heritability for plant breeding: An update. Plant Breeding Reviews, 22, 9-112.

Law, C. N., Sutka, J., \& Worland, A. J. (1978). A genetic study of daylength response in wheat. Heredity, 41(2), 185-191. https://doi.org/ 10.1038/hdy.1978.87

Lázaro, L., \& Abbate, P. E. (2012). Cultivar effects on relationship between grain number and photothermal quotient or spike dry weight in wheat. Journal of Agricultural Science, 150(4), 442-459. https://doi.org/10.1017/S0021859611000736

Mahjourimajd, S., Taylor, J., Sznajder, B., Timmins, A., Shahinnia, F., Rengel, Z., Khaz-Saberi, H., Kuchel, H., Okamoto, M., Langridge, P. (2016). Genetic basis for variation in wheat grain yield in response to varying nitrogen application. PLoS ONE, 11(7), 1-18.

Martino, D. L., Abbate, P. E., Cendoya, M. G., Gutheim, F., Mirabella, N. E., \& Pontaroli, A. C. (2015). Wheat spike fertility: Inheritance and relationship with spike yield components in early generations. Plant Breeding, 134(3), 264-270. https://doi.org/10.1111/pbr.12262

Mirabella, N. E., Abbate, P. E., Ramirez, I. A., \& Pontaroli, A. C. (2016). Genetic variation for wheat spike fertility in cultivars and early breeding materials. Journal of Agricultural Science, 154(1), 13-22. https://d oi.org/10.1017/S0021859614001245

Parry, M. A., Reynolds, M., Salvucci, M. E., Raines, C., Andralojc, P. J., Zhu, X. G., Price, G. D., Condon, A. G., Furbank, R. T. (2011). Raising yield potential of wheat. II. Increasing photosynthetic capacity and efficiency. Journal of Experimental Botany, 62(2), 453-467. https://doi. org/10.1093/jxb/erq304

Piepho, H.-P., \& Möhring, J. (2007). Computing heritability and selection response from unbalanced plant breeding trials. Genetics, 177, 18811888. https://doi.org/10.1534/genetics.107.074229

Rajaram, S. (2005). Role of conventional plant breeding and biotechnology in future wheat production. Turkish Journal of Agriculture and Forestry, 29, 105-111.

Reynolds, M. P., Foulkes, M. J., Slafer, G. A., Berry, P., Parry, M. A., Snape, J. W., Angus, W. J. (2009). Raising yield potential in wheat. Journal of Experimental Botany, 60(7), 1899-1918. https://doi.org/10.1093/jxb/ erp016

Scarth, R., \& Law, C. N. (1983). The location of the photoperiod gene, Ppd2 and an additional genetic factor for ear-emergence time on chromosome 2B of wheat. Heredity, 51(3), 607-619. https://doi.org/ 10.1038/hdy.1983.73

Shearman, V. J., Sylvester-Bradley, R., Scott, R. K., \& Foulkes, M. J. (2005). Crop physiology and metabolism. Physiological processes associated with wheat yield progress in the UK. Crop Science, 45, 175-185.

Slafer, G. A., Abeledo, L. G., Miralles, D. J., Gonzalez, F. G., \& Whitechurch, E. M. (2001). Photoperiod sensitivity during stem elongation as an avenue to raise potential yield in wheat. Euphytica, 119, 191197. https://doi.org/10.1023/A:1017535632171

Slafer, G. A., Andrade, F. H., \& Satorre, E. H. (1990). Genetic-improvement effects on pre-anthesis physiological attributes related to wheat grain-yield. Field Crops Research, 23(3-4), 255-263. https://doi.org/ 10.1016/0378-4290(90)90058-J

Slafer, G. A., Calderini, D. F., \& Miralles, D. J. (1996). Yield components and compensation in wheat: Opportunities for further increasing yield potential. In M. P. Reynolds, S. Rajaram, \& A. McNab (Eds.), Increasing yield potential in wheat: Breaking the barriers (pp. 101-133). Mexico, DF: CIMMYT.

Slafer, G. A., Elia, M., Savin, R., García, G. A., Terrile, I. I., Ferrante, A., Miralles, D. J., González, F. G. (2015). Fruiting efficiency: An alternative trait to further rise wheat yield. Food and Energy Security, 4(2), 92-109. https://doi.org/10.1002/fes3.59

Vanzetti, L. S., Yerkovich, N., Chialvo, E., Lombardo, L., Vaschetto, L., \& Helguera, M. (2013). Genetic structure of Argentinean hexaploid wheat germplasm. Genetics and Molecular Biology, 36(3), 391-399. https://doi.org/10.1590/S1415-47572013000300014

Welsh, J. R., Kein, D. L., Pirasteh, B., \& Richards, R. D. (1973). Genetic control of photoperiod response in wheat. In: E. R. Sears \& L. M. Sears (Eds.), Proceedings of the 4th International Wheat Genetics Symposium (pp. 879884). Missouri, USA: Experimental Station, University of Missouri.

Whitechurch, E. M., \& Slafer, G. A. (2002). Contrasting Ppd alleles in wheat: Effects on sensitivity to photoperiod in different phases. Field Crops Research, 73(2-3), 95-105. https://doi.org/10.1016/S03784290(01)00188-5

Worland, A. J. (1996). The influence of flowering time genes on environmental adaptability in European wheats. Euphytica, 89(1), 49-57. https://doi.org/10.1007/BF00015718

Worland, A. J., Börner, A., Korzun, V., Li, W. M., Petrovic, S., \& Sayers, E. J. (1998). The influence of photoperiod genes on the adaptability of European winter wheats. Euphytica, 100(1), 385-394. https://doi.org/ 10.1023/A:1018327700985

Worland, A. J., Petrovic, S., \& Law, C. N. (1988). Genetic analysis of chromosome 2D of Wheat II. The importance of this chromosome to Yugoslavian varieties. Plant Breeding, 100, 247-259. https://doi.org/ 10.1111/j.1439-0523.1988.tb00250.x

\section{SUPPORTING INFORMATION}

Additional Supporting Information may be found online in the supporting information section at the end of the article.

How to cite this article: Ramirez IA, Abbate PE, Redi IW, Pontaroli AC. Effects of photoperiod sensitivity genes Ppd-B1 and $P p d-D 1$ on spike fertility and related traits in bread wheat. Plant Breed. 2018;137:320-325. https://doi.org/10.1111/ pbr.12585 